\title{
The Implementation Approach of LCCF Checklist in Development Control: Challenges for policymakers
}

\author{
Siti Kartina Juhari, Dasimah Omar, Oliver Ling Hoon Leh, Siti Mazwin Kamarudin \\ Department of Town \& Regionnal Planning, Faculty of Architecture, Planning and Surveying, \\ Universiti Teknologi MARA, Shah Alam, Selangor, Malaysia. \\ kartinauitm@gmail.com, dasimaho@yahoo.com, oliverling.my@gmail.com, sitim065@uitm.edu.my \\ Tel: +6013-7340737
}

\begin{abstract}
Low carbon cities are the effort of the leaders in achieving sustainable development. The gap is despite the LCCF Checklist is readied but not all implement in planning permission at the local authority. The objective is to study a challenge for policymakers in the approach of the LCCF Checklist in development control. The methodology is a mixed-method, namely quantitative and qualitative approaches. The findings of the LCCF checklist are identifying as important in planning permission into the development control process. Surprisingly, the challenges exist in the implementation of the LCCF Checklist in the development control process.
\end{abstract}

Keywords: Low Carbon Cities Framework (LCCF) Checklist, Local Authority, Planning Permission, Sustainable Development Goals

eISSN: 2398-4287 @ 2019. The Authors. Published for AMER ABRA cE-Bs by e-International Publishing House, Ltd., UK. This is an open access article under the CC BYNC-ND license (http://creativecommons.org/licenses/by-nc-nd/4.0). Peer-review under responsibility of AMER (Association of Malaysian Environment-Behaviour Researchers), ABRA (Association of Behavioural Researchers on Asians) and cE-Bs (Centre for Environment-Behaviour Studies), Faculty of Architecture, Planning \& Surveying, Universiti Teknologi MARA, Malaysia.

DOI: https://doi.org/10.21834/e-bpj.v4i12.1804

\subsection{Introduction}

Cities are the major players of the carbon emission to combat global warming and climate change (Gargiulo et al., 2017). Climate change is affecting in a world. It is referred to as the observed scale, increasing the temperature. The world like ice cream it is related to the earth's climate change because the problem has resulted in environmental degradation. Based on the Sustainable model by Mc Donough the term cradle to grave is the perspective on the approach the environmental (Khan, n.d.). The effort of the leaders divides by two is named the national level and the local authority level. Firstly is the context national level at New Urban Agenda (NUA) is the action blueprint for UN-Habitat with stakeholders to support the 2030 agenda towards sustainable development. According to the Sustainable Development Goals (SDG) have 17 goals. Refer to the SDG number 11 to sustainable cities and communities. It is also related to SDG's number 13 to take urgent action to combat climate change and the impact of the environment. Hence the effort of the leaders of the local authorities is the approaches for the Low Carbon Cities Framework.

Low Carbon City relates to carbon minimization in all sectors contributed by communities to achieve a better quality of life. Health and interaction with promoting the technologies friendly for the utilization of biomass are expected soon by manifesting in LCCF (Ho, 2011). The LCCF will assist local authorities and developers to achieve low carbon city status, providing a framework and tools to implement strategies that will reduce carbon emissions by phases. The LCCF was developed by the Ministry of Energy, Green Technology and Water (MEGTW) in collaboration with the Malaysian Green Technology Corporation (MGTC) to facilitate local authorities and township developers and designers in the development of Low Carbon Cities in Malaysia. It will help users assess their current baseline and provide them with insights on how carbon emissions levels can be reduced in development projects.

According to the Low Carbon Cities Framework, the LCCF is not a rating system. It is a performance-based system and these comprising four (4) elements, namely Urban Environment, Urban Infrastructure, Urban Transportation and Building. These elements have 15 criteria and 41 sub-criteria. (Ministry of Energy, 2017). The measurement of strategies to reduce carbon emission is based on

eISSN: 2398-4287 @ 2019. The Authors. Published for AMER ABRA CE-Bs by E-International Publishing House, Ltd., UK. This is an open-access article under the CC BY-NC-ND license (http://creativecommons.org/licenses/by-nc-nd/4.0/). Peer-review under responsibility of AMER (Association of Malaysian Environment-Behaviour Researchers), ABRA (Association of Behavioural Researchers on Asians) and cE-Bs (Centre for Environment-Behaviour Studies), Faculty of Architecture, Planning \& Surveying, Universiti Teknologi MARA, Malaysia.

DOI: https://doi.org/10.21834/e-bpj.v4i12.1804 
performance criteria for low carbon cities. The measurement according to the Low Carbon Cities Framework the LCCF is not a rating system. It is a performance-based system and these comprising four (4) elements, namely Urban Environment, Urban Infrastructure, Urban Transportation and Building. These elements have 15 criteria and 41 sub-criteria. (Ministry of Energy, 2017). The measurement of strategies to reduce carbon emission is based on performance criteria for low carbon cities. The measurable strategies are to reduce carbon emission through policymaker, transformation in the procurement system, development of technology and a better process at a local authority level. Why we focus on the city because the city contributes the carbon emission. The city must determine the area of concern to measure the performance criteria for the effort. According to the Local Government Act 1976 (Act 171) under Section 4, Subang Jaya Municipal Council (MPSJ) is a local government had been established. MPSJ should apply the LCCF Checklist in planning permission. As refer to Agenda 21, the role of local government is crucial in the sustainable development LCCF Checklist is very important as a tool for development control. Since MPSJ had taken the effort in implementing the LCCF Checklist into the planning permission, the effectiveness of the implementation should be studied.

Currently, the implementation of the LCCF Checklist into planning permission is surprisingly not been studied in detail strategies are to reduce carbon emission through policymaker, transformation in the procurement system, development of technology and a better process at a local authority level. Why we focus on the city because the city contributes the carbon emission. The city must determine the area of concern to measure the performance criteria for the effort. According to the Local Government Act 1976 (Act 171) under Section 4, Subang Jaya Municipal Council (MPSJ) is a local government had been established. MPSJ should apply the LCCF Checklist in planning permission. As refer to Agenda 21, the role of local government is crucial in the sustainable development LCCF Checklist is very important as a tool for development control. Since MPSJ had taken the effort in implementing the LCCF Checklist into the planning permission, the effectiveness of the implementation should be studied. Currently, the implementation of the LCCF Checklist into planning permission is surprisingly not been studied in detail.

\subsection{Literature Review}

\subsection{Low Carbon Cities Globally}

Low Carbon Cities had been implemented globally and defined slightly different names as a reference to a city, province, municipality, or community that relates a systematic process to achieve GHG emission reductions. (Asia Leds Partnerships, 2013). There were a few case studies in Asia and Europe. Issues were addressed, the approach was taken contextualized locally. The rapid urbanization causes rapid environmental degradation demanded with less energy for the new development pattern. The new concept of Low Carbon City namely the eco-city was among the answer. Implementing the concept requires the change in the development mode from only focusing on economic growth to an equal focus on the social and environmental aspects in the planning process that had taken place in Shenzhen, China (Ruben Cales, 2014). Another example was the UK is Oxford City Council. In 2008 City Council created a Carbon Management Plan aimed to reduce the City Council's emissions by 25\% by 2011 with its measures (Paul Wedgwood, 2015).

\subsection{Low Carbon Cities Framework (LCCF) in Malaysian Local Authority}

Low Carbon Cities Framework (LCCF) in Malaysian Local Authority has two groups of users of this LCCF document which are the local authorities and stakeholders in the city or town. The following points will detail the implementation of the LCCF about the two different user groups is namely local authority level and stakeholders level. Local authorities will play a major role in undertaking policy initiatives to reduce carbon emissions of the city. Besides local authorities, stakeholders also play an important role in lowering the carbon emissions of a city. The stakeholders can be developed, registered town planners or designers.

\subsection{Low Carbon Cities Framework (LCCF) Checklist and Planning Permission}

To date, the LCCF only established until only at the planning permission stage and argue to be too general by the Malaysia Institute of Planner (MIP, 2016). The assessment takes place in the development planning permission stage as part of the need statement for the future project undertaking somehow may need revision. It is also fewer practices the implementing of LCCF in a local authority for the stakeholders to assist those who involve in a development project be it developers, professionals, consultants and local authorities in evaluating the carbon emissions level (MIP, 2016).

LCCF Checklist is a tool for planning permission. Subang Jaya Municipal Council is using the LCCF Checklist especially for the development control of density and plot ratio. Now a day the application of LCCF Checklist Planning Permission is applied for Planning Permission layout plan and Planning Permission erection of a building or freestanding building. The application of the LCCF checklist is one of the options for developers within the plot ratio guidelines within the MPSJ area based on certain criteria. These guidelines have been approved by the Selangor State Planning Committee in 2015 to approve the increase in plot ratio of the areas involved with the Transit-Oriented Development (TOD) concept. However, the purpose of the application LCCF Checklist in planning permission is not limited to the plot ratio increase but also to implement green initiatives in development control. The application of this Checklist is aimed at Develop a rating system for developers adopting the LCCF Checklist and Recommendation rating systems and incentives to developers implementing green initiatives in development control.

\subsection{Element LCCF Checklist}

The four elements of the LCCF checklist are based on the element LCCF is further categorized into 15 performance criteria and 41 subcriteria, each of which provides specific intents towards carbon reduction targets. 
Table 1: Element, Score, Performance Criteria and Sub Criteria for LCCF

\begin{tabular}{|c|c|c|c|c|}
\hline 4 Element & Performance Criteria & Score & $\begin{array}{l}15 \text { Performance } \\
\text { Criteria }\end{array}$ & 41 Sub Criteria \\
\hline \multirow{4}{*}{ Urban Environment (UE) } & - UE 1: Site Selection & 10 & \multirow{4}{*}{3} & \multirow{4}{*}{14} \\
\hline & - UE 2: Urban Form & 18 & & \\
\hline & - UE 3: Urban Greenery and Environmental Quality & 9 & & \\
\hline & Total Criteria Achieved for UE & 37 & & \\
\hline \multirow{7}{*}{ Urban Transportation (UT) } & $\begin{array}{l}\text { - UT 1: Reduction Use of Private Motorised Transport on } \\
\text { Urban Road Network }\end{array}$ & 8 & \multirow{7}{*}{6} & \multirow{7}{*}{11} \\
\hline & - UT 2: Increase in Public Transport & 5 & & \\
\hline & $\begin{array}{l}\text { - UT 3: Mode Shift from Private to Public Transport and } \\
\text { Non-Motorised Transport }\end{array}$ & 5 & & \\
\hline & - UT 4: Use of Low Carbon Transport & 4 & & \\
\hline & $\begin{array}{l}\text { - UT 5: Improvement to Level of Service of Road Links } \\
\text { and Junctions }\end{array}$ & 2 & & \\
\hline & $\begin{array}{l}\text { - UT 6: Utilisation of Transit-Oriented-Development (TOD) } \\
\text { Approach }\end{array}$ & 5 & & \\
\hline & Total Criteria Achieved for UT & 29 & & \\
\hline \multirow{5}{*}{ Urban Infrastructure (UI) } & - UI 1: Infrastructure Provision & 9 & \multirow{5}{*}{4} & \multirow{5}{*}{10} \\
\hline & - UI 2: Waste & 10 & & \\
\hline & - UI 3: Energy & 3 & & \\
\hline & - "Ul 4: Water Management & 4 & & \\
\hline & - Total Criteria Achieved for UI & 26 & & \\
\hline \multirow{3}{*}{ Building (B) } & - B 1: Sustainable Energy Management System & 3 & \multirow{3}{*}{2} & \multirow{3}{*}{6} \\
\hline & - B 2: Low Carbon Buildings & 10 & & \\
\hline & Total Criteria Achieved for UB & 13 & & \\
\hline
\end{tabular}

\subsection{LCCF Checklist And Planning Permission}

The assessment takes place in the development planning permission stage as part of the need statement for the future project undertaking somehow may need revision. Besides, there is a dearth of literature critically discussing the LCCF checklist globally much less the Malaysian LCCF checklist. Vagueness in understanding and implementing LCCF in local authority much less the construction industry is identified with promoting LCCF. Planning permission is a procedure in which the applicant must submit an application to the local planning authority for approval before starting any development on their land or building as provided under section $21 \mathrm{~A}$ of the [Development Proposal Report (LCP)] and section 21B [Layout Plan] (Act 172, 1974). Development control is the process of regulating the use of land and buildings by the local planning authority. Definition of development in Section 2 of the Town and Country Planning Act 1976 (Act 172) is defined as the carrying out of building, engineering, mining, industrial or other operations in, on, over or under land or the making of any material in the use of any buildings or other land or part of or to subdivide or amalgamate the land; and; "development" should be defined accordingly (Act 172, 1976).

\subsection{Methodology}

The selected case study area is the Subang Jaya Municipal Council. It consists of five (5) zones, namely Subang Jaya, Kinrara, Puchong, Seri Kembangan, and Putra Permai. However, this research is only focusing on Subang Jaya, Sunway, Putra Heights, USJ and Puchong. The study will apply an exploratory research design (non-experimental research design) to achieve the research aim and objectives. Research methods that are applied in this research are qualitative and quantitative approaches. Quantitative data in this study will be from stakeholders and the community. The quantitative approaches to the stakeholders are collected in the first stage by using the structured questionnaire to identify the emphasized data on local authority and stakeholders, namely developer, consultant, and technical agencies which related to One Stop Centre (OSC) meeting. Respondents for the questionnaire survey which be selected by using stratified sampling. Qualitative data collection is from the interview with town planning officers in a local authority for the expert survey. The quantitative data will be analyzed by the system using the Statistical Packaging for Social Science (SPSS version 23). The descriptive analysis will be used because it can explore the stakeholders' attention and willingness to implement the LCCF Checklist.

This research is going to explore the 4 elements of the LCCF Checklist, i.e. the stakeholders' willingness and perception, effort, knowledge and pro-active attitude in implementing LCCF / Low Carbon Cities based on figure 1: Conceptual Framework: Relationship Between Variables. Cross-tabulation and correlation tests will be used to further analyze the factors and the relationship between the variables. This research is focused to study translating the Low Carbon Cities Framework (LCCF) checklist into planning permission in a local authority towards green cities. This paper is focused to study the challenges and policymakers in the readiness of LCCF Checklist implementation by stakeholders as the local authority, developer, consultant, and technical agencies. It is also to investigate the achievement of LCCF of the aspects of Economy, Social, and Environment towards sustainable development as figure 1 below. 


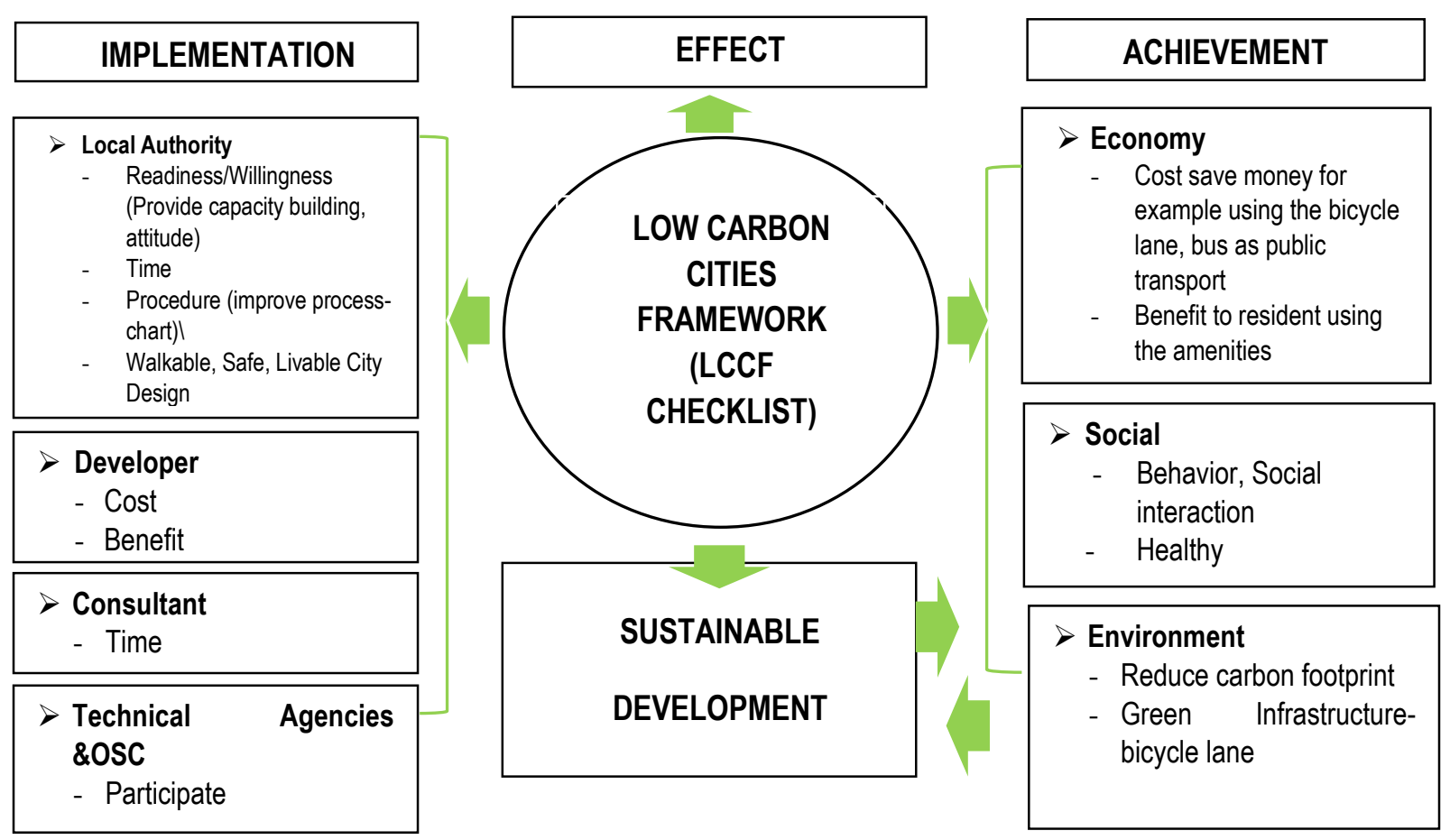

Figure 1: Conceptual Framework: Relationship between variables

\subsection{Findings}

The finding of this research is Local Authority plays a major role in manifesting the LCCF Checklist in development control. The result of this paper is LCCF Checklist must incorporated in the LCP. The element in the plan should be elaborated in the LCP. Based on the lab session mostly the participation the LCCF choose the LCCF incorporated with LCCF Checklist. Hence the element and the performance criteria must behave stated into the LCP. All the implementation in the layout plan must-have in the LCP. The table 2 is an interview with the Local Authorities in implementation of the LCCF checklist are refer to table 1 is Element, Score, Performance Criteria and Sub Criteria for LCCF. The challenges are the layout plan LCCF Checklist surprisingly not easy to the officer to check the plan. To solve this problem local authorities should have a lab and seminar to enhance the level of knowledge about application LCCF checklist in development control. The local authority also should give incentive(s):e.g. plot ratio. However, the policymaker must give the penalty should be given to those who failed to comply with the projected $\mathrm{CO} 2$ reduction. The mechanism to be right. To monitor at the federal level as policymakers LCCF needs to tackle the decision-maker federal level (KPKT and PLANMalaysia/JPBD) to make the implementation more effective and successful. There are also needed to have a "lab session" at the State level. This can be linked with the "Low Carbon State" idea. Lastly, the local authority should organize a Master Class session with developers and stakeholders.

\subsection{Discussions}

LCCF criteria must be studied and detailed to ease the understanding and implementation of local authority and stakeholders of the construction industry. Local authority within its jurisdiction has a real responsibility to be part of the leader in developing a more recognized, and applicable LCCF framework internally and for the industry. Local authority plays a major role in manifesting LCCF is a newly developed project, but few challenges must highlight the effectiveness and applicability of the implementation of the LCCF Checklist. The input from the local authorities and developers must be strengthening for further improvement of the LCCF Checklist.

LCCF criteria must be studied and detailed to ease the understanding and implementation of local authority and stakeholders of the construction industry. Local authority within its jurisdiction has a real responsibility to be part of the leader in developing a more recognized, and applicable LCCF framework internally and for the industry. Local authority plays a major role in manifesting LCCF is a newly developed project, but few challenges must highlight the effectiveness and applicability of the implementation of the LCCF Checklist. The input from the local authorities and developers must be strengthening for further improvement of the LCCF Checklist. 


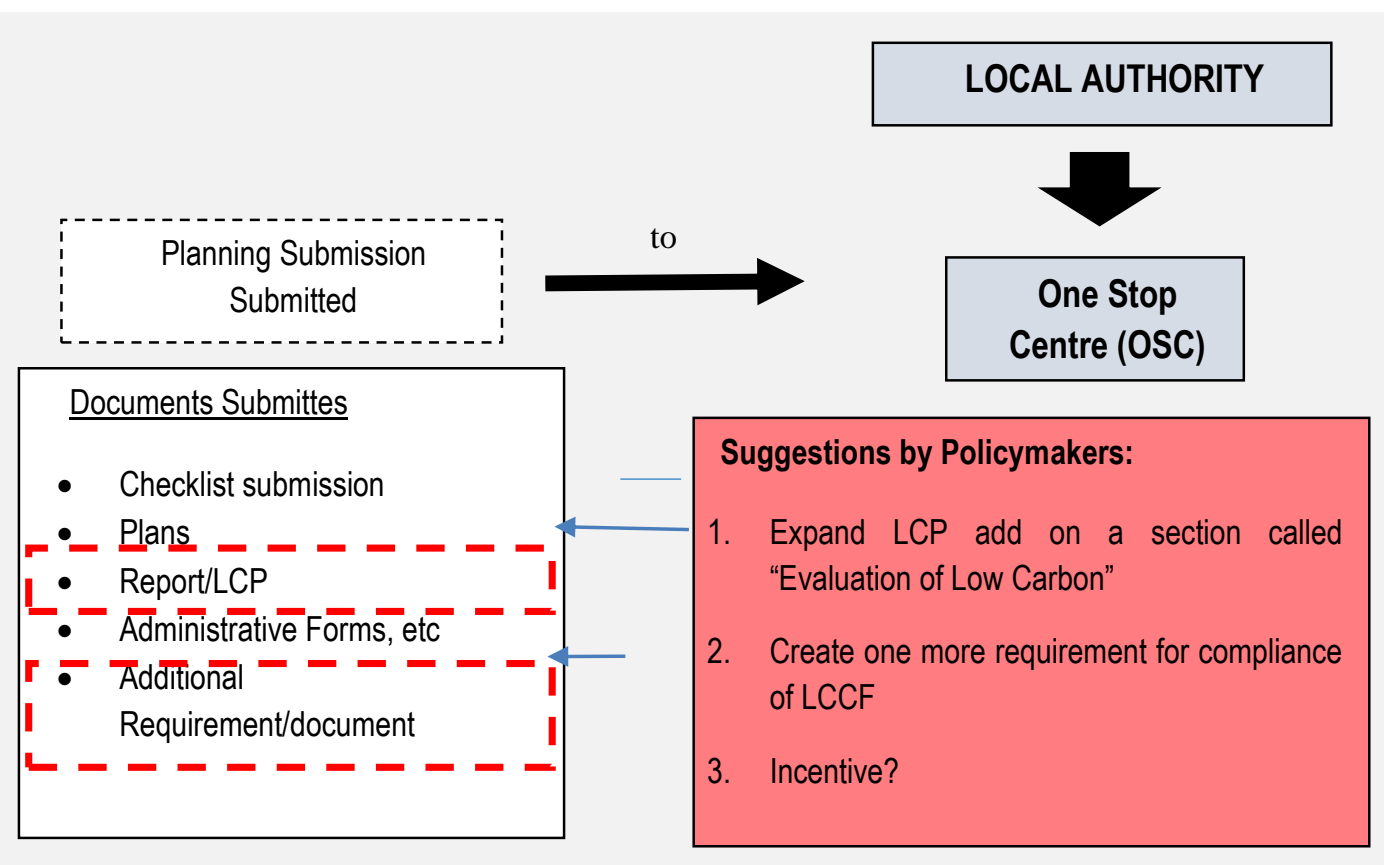

Figure 1 : Incorporating LCCF in The Planning Approval Process

Table 2. Interview with the Local Authorities in Implementation of LCCF Checklist by local authority as policy makers

\begin{tabular}{|c|c|c|c|c|}
\hline Item & Local Authority & & Issues & $\begin{array}{l}\text { Implementation } \\
\text { LCCF Checklist }\end{array}$ \\
\hline \multirow[t]{4}{*}{1.} & \multirow[t]{4}{*}{ MBSA } & 1. & $\begin{array}{l}\text { LCCF should be incorporated in the LCP. However, the person in charge } \\
\text { to evaluate must be someone who knows/understand the LCCF very well. }\end{array}$ & \multirow[t]{4}{*}{$\begin{array}{l}\text { LCCF Checklist for the } \\
\text { Project Brief }\end{array}$} \\
\hline & & 2. & $\begin{array}{l}\text { Identify where LCCF can be incorporated in LCCF Checklist too (KM } \\
\text { erection of building) }\end{array}$ & \\
\hline & & 3. & $\begin{array}{l}\text { The progress report can be done yearly or periodically. For example, the } \\
\text { progress report for the overall master plan as well as a phasing plan }\end{array}$ & \\
\hline & & 4. & $\begin{array}{l}\text { The mechanism needs to be detailed out. Incentives need to have intensive } \\
\text { guidelines }\end{array}$ & \\
\hline \multirow[t]{2}{*}{2.} & \multirow[b]{2}{*}{ MBPJ } & 1. & LCCF should be incorporated in the Development Proposal Report (LCP) & \multirow{2}{*}{$\begin{array}{l}\text { Low Carbon Society } \\
\text { (LCS) and }\end{array}$} \\
\hline & & 2. & $\begin{array}{l}\text { Possible incentive(s):e.g. plot ratio. However, the penalty should be given to } \\
\text { those who failed to comply with the projected } \mathrm{CO} 2 \text { reduction. The mechanism } \\
\text { to be right. }\end{array}$ & \\
\hline \multirow[t]{5}{*}{3.} & \multirow[t]{5}{*}{ PJC } & 1. & $\begin{array}{l}\text { LCCF can be incorporated in the LCP. However, the format of evaluation } \\
\text { to be developed for consistency, maybe in a form a Checklist. }\end{array}$ & \multirow[t]{5}{*}{$\begin{array}{l}\text { Low Carbon Society } \\
\text { (LCS) }\end{array}$} \\
\hline & & 2. & $\begin{array}{l}\text { The checklist can be upgraded or changed over time, maybe every } 3 \text { to } 6 \\
\text { months. }\end{array}$ & \\
\hline & & 3. & Categorize based on the scale of development/project. & \\
\hline & & 4. & $\begin{array}{l}\text { LCCF needs to tackle the decision-maker (KPKT and } \\
\text { PlanMalaysia/JPBD) to make the implementation more effective and } \\
\text { successful. }\end{array}$ & \\
\hline & & 5. & WHO to monitor? & \\
\hline \multirow[t]{3}{*}{4.} & \multirow[t]{3}{*}{ MPSJ } & 1. & $\begin{array}{l}\text { LCCF would the best incorporated in the LCP as "Kaedah". Refer Act 172, } \\
\text { Section } 58 \text { (i) and (ii): "Power To Make Rules". }\end{array}$ & \multirow[t]{3}{*}{ LCCF Checklist } \\
\hline & & 2. & $\begin{array}{l}\text { There's needed to have a "lab session" at the State level. This can be linked } \\
\text { with the "Low Carbon State" idea. }\end{array}$ & \\
\hline & & 3. & $\begin{array}{l}\text { MPSJ will organize a Master Class session with developers 2015. A teach-in } \\
\text { session on LCCF will be the main agenda to ensure that developers embrace } \\
\text { the LCCF and in the long run help, MPSJ achieves a low carbon city status. }\end{array}$ & \\
\hline
\end{tabular}




\subsection{Conclusion \& Recommendations}

In conclusion, this article had reviewed the existing application of the LCCF Checklist in planning permission. How to quantum leap the approaches of the environment is from the policymakers to the developer. It is also to do improvement an abrupt change and dramatic advance is from the effort of the leader which is the national and local level. Surprisingly, that challenges to the implementation of the local authority and not been closely examined. Despite the importance of LCCF Checklist in development control, local authority plays a major role of manifesting LCCF in newly develop the project but few challenges must be the highlight. The element of the LCCF Checklist into planning permission must be studied and detailed to ease the understanding and implementation of local authority and stakeholders of the development control. The Implementation approach of the LCCF Checklist in development control is to give challenges for policymakers and decision-makers. The recommendations are expanding LCP add on a section called "Evaluation of Low Carbon Cities". It is also to Incorporating LCCF Checklist in The Planning Approval Process. Finally, the existing approach in the application of the LCCF Checklist in the development control process will be useful for development control in a local authority towards sustainable development.

\section{Acknowledgement}

The authors would like to thank Universiti Teknologi MARA (UiTM) for the support and partly funding the study and publication through the research grant [(600-IRMI/FRGS 5/3 (406/2019)]. The authors are also thankful to all the departments, organisations, and individual who had contributed to this study.

\section{References}

Act 172. (2001). Town and Country Planning Act 1976 [Act 172] (Malaysia), 9

Asia Leds Partnerships. (2013). Case Studies on Low Emission Development, Thailand's Low Carbon City Initiatives, Thailand (Electronic Materials), Asia-LEDSPartnership-Case-Study-Thailand-Low-Carbon-City-Initiative-March-2013), 1

Abdul-Azeez, I.A. (2012). The Development and Application of Malaysian University Campus Emission Tool (MUCET) Towards Creating Sustainable Campus. PhD Thesis Faculty of Built Environment, Universiti Teknologi, Malaysia.

Dato' Sri Peter Chin Fah Kui (2011). LCCF Book (Minister of Energy, Green Technology and Water, Malaysia)

Gargiulo, M., Chiodi, A., De Miglio, R., Simoes, S., Long, G., Pollard, M., ... Giannakidis, G. (2017). An Integrated Planning Framework for the Development of Sustainable and Resilient Cities - The Case of the InSMART Project. In Procedia Engineering. https://doi.org/10.1016/j.proeng.2017.07.099

Ho Chin Siong. (2011). Low Carbon cities - the way forward for real estate development at Conference on Mixed use development, Crown Plaza Mutiara, Kuala Lumpur, October 17-18, 2011 (Electronic Materials) (International Journal of Real Estate Studies, Volume 8, Number 1), 1

Ho, C.S. (2011). Green and low carbon cities in Malaysia - the case of Putrajaya and Cyberjaya, presented Gren Building forum /DATUM Kuala Lumpur Architecture Festival 2011, Kuala Lumpur Convention Centre, 30 June 2011.

Ho Chin Siong, Abdul-Azeez and Isiaka Adeyemi, (2013) International Journal of Real Estate Studies, (Universiti Teknologi Malaysia, Faculty of Built Environment, UTM Johor, Malaysia) (International Journal of Real Estate Studies, Volume 8, Number 1), 1

Khan, A. Y. (n.d.). Special Report A Cradle to Grave Approach : An Effective Solution for Reduction in Environmental Pollution, 2006

Malaysian Institute Of Planners (MIP) (2015), Lab Session Application Of LCCF Checklist And Calculator In Achieving Low Carbon Property Development (Grand Dorsett Hotel, Subang Jaya, Malaysia)

Ministry of Energy, G. T. and W. (KeTTHA). (2017). Lo w ca r bo n Cities Framework. Low Carbon Cities Framework, Version 2(ISBN 978-967-5893-10-0, Malaysia).

Ministry of Energy, G. T. and W. (KeTTHA). (2017). Lo w ca r bo n. Low Carbon Cities Framework, Version 2 (ISBN 978-967-5893-10-0), Pusat Pentadbiran Kerajaan Persekutuan, Putrajaya.

Ministry of Energy, (2012) Green Technology and Water, Malaysia (KeTTHA), Low Carbon Cities Framework Book, Putrajaya

Ministry Of Energy, Green Technology and Water (KeTTHA) (2013). Low Carbon Cities Framework \& Assessment System, Pusat Pentadbiran Kerajaan Persekutuan, Putrajaya.

Onishi, T. and Kobayashi, H. (2011). Low Carbon Cities - The Future of Urban Planning. Master's Program in Sustainable Regeneration Series. Department of Urban Engineering, Graduate School of Engineering, the University of Tokyo.

Ruben Cales. (2014). Shenzhen Low Carbon City: A transformation of Concept and Planning Process (University of Amsterdam, Graduate School of Social Science, Department of Human Geography, Planning \& International Development Studies)

Paul Wedgwood. (2015) A Strategic Framework For Low Carbon Cities (General Manager Scotland) 